\title{
Effects of the invasive clam Corbicula fluminea (Müller, 1774) on a representative macrobenthic community from two estuaries at different stages of invasion
}

\author{
Eduardo Sampaio and Iván F. Rodil \\ Laboratory of Coastal Biodiversity. CIIMAR/CIMAR-Interdisciplinary Centre for Marine and Environmental \\ Research, Rua dos Bragas 289, 4050-123 Porto, Portugal. \\ * Corresponding author: edusilvasampaio@gmail.com
}

Received: 26/12/2013

Accepted: 21/05/2014

\begin{abstract}
Relationships between the invasive clam Corbicula fluminea (Müller, 1774) and a representative macrobenthic community from two estuaries at different stages of invasion

The introduction of non-indigenous species (NIS) is one of the main reasons for the loss of biodiversity worldwide. This phenomenon has increased dramatically in recent decades leading to a reduction of the availability of ecosystem goods and services. One of the most important invasive species in aquatic ecosystems is the Asian clam, Corbicula fluminea (Müller, 1774). In this work, we compared the benthic macroinvertebrate assemblages in the freshwater section of two river estuaries, Lima and Minho, which were invaded with a 12 -year gap by this non-indigenous bivalve. This study shows that $C$. fluminea's presence can model other species' abundance in a strong fashion, especially in the later stages of invasion when it is fully settled. Although our results showed that the abundance of this invasive bivalve is linked to high values of biodiversity and to direct increases in the abundance of Gastropoda, an invasion by $C$. fluminea seems to prompt negative effects on specific crustacean species, such as the abundant amphipod species Corophium multisetosum. We propose that the dominance of one competitive species, coupled with favourable abiotic factors, may hinder the progress of $C$. fluminea's invasion.
\end{abstract}

Key words: Alien species, freshwater, biodiversity, estuary, benthos, invertebrates.

\section{RESUMEN}

Relaciones entre el bivalvo invasor Corbicula fluminea (Müller, 1774) y las asociaciones macrobentónicas representativas en dos estuarios con diferentes estados de invasión

La introducción de especies no-indígenas (NIS) es una de las razones principales de la pérdida de biodiversidad a nivel mundial, y este fenómeno ha aumentado dramáticamente en décadas recientes, llevando a una reducción en los bienes y servicios proporcionados por los ecosistemas. Una de las especies invasoras más importantes en los ecosistemas acuáticos a nivel mundial es el bivalvo asiático, Corbicula fluminea (Müller, 1774). En este estudio, tomamos muestras de sedimento de la parte dulceacuícola de dos ríos estuáricos, Lima y Miño, que fueron invadidos por este bivalvo no-indígena en diferentes años. Este estudio muestra que la presencia de C. fluminea puede modelar considerablemente la abundancia de otras especies, especialmente en estadios invasivos avanzados. Aunque nuestros resultados mostraron que la abundancia de este bivalvo invasor está relacionada con una alta biodiversidad y aumentos directos en la abundancia de gasterópodos, la invasión por C. fluminea parece provocar efectos negativos en algunas especies de crustáceos, como el abundante anfípodo Corophium multisetosum. Proponemos que la dominancia de una especie competitiva, junto con factores abióticos favorables, puede dificultar el progreso invasor de $\mathrm{C}$. fluminea.

Palabras clave: Especies invasoras, agua dulce, biodiversidad, estuario, bentos, invertebrados. 


\section{INTRODUCTION}

The introduction of non-indigenous species (NIS) is one of the main reasons for the loss of biodiversity worldwide due to their competition for habitat and nutrient resources with native species (Stachowicz et al., 2002). In extreme situations, NIS can be responsible for a full replacement of the native species, affecting the integrity of aquatic ecosystems (Human \& Gordon, 1996; Mack \& D’Antonio, 1998; Fogarty \& Facelli, 1999; Gherardi \& Daniels, 2005). In aquatic environments, this phenomenon has increased dramatically in recent decades, largely because of tourism and global trade, impacting several trophic levels in different ecosystems, including coastal waters, rivers and estuaries (Hartog et al., 1992); Lodge, 1993; Drake \& Lodge, 2007). This is of global concern because biodiversity contributes to ecosystem goods and services of ecological and socio-economic value, such as providing sustainable food webs. For instance, a decrease of biodiversity in a base level of the trophic web (e.g., molluscs) could lead to a collapse in the abundance of predatory commercial fishes, in case that fish does not feed on the introduced species (e.g., Worm et al., 2006; Sousa et al., 2008a).

One of the most widespread invasive species in aquatic ecosystems is the Asian clam, Corbicula fluminea (Müller, 1774) (Minchin, 2008). Due to its reproductive $r$-strategy (i.e., considerable genetic variability and phenotypic plasticity, short lifespan, rapid growth, high fecundity and early sexual maturation), extremely high filtration rate and nutrient assimilation (McMahon, 2000; 2002), C. fluminea has spread successfully in river and estuarine ecosystems in North America, South America and Europe, eliminating its competitors (McMahon, 1982; Araujo et al., 1993; Ituarte, 1994). The colonising process of this invasive species can lead to repercussions in the food webs and biogeochemical cycles due to direct competition with native species and the clam's strong capability to influence the availability of phytoplankton and nutrient resources in the new hosting ecosystem (Sousa et al., 2008b; Sousa et al., 2009). Although there are some reports of some faunistical groups responding positively to $C$. fluminea's abundance (Ilarri et al. 2012), the introduction of this invasive species has been shown to diminish the abundance and diversity of macro and micro-fauna in North America and Europe (Hakenkamp et al., 2001; McMahon, 2002) and also to reduce sediment quality (Nguyen \& Pauw, 2002). Therefore, this invasive species holds the feasible ability to reduce the overall biological quality in aquatic ecosystems.

In Portugal, C. fluminea was first reported in 1981 in the River Tejo estuary (Mouthon, 1981), presumably after having been transported by cargo ships' ballast and/or hull fouling from North America (Elliott \& zu Ermgassen, 2008). This species has been found across different sections of the estuaries, from aquatic to brackish environments, showing a high tolerance to a broad range of salinity variance, which benefits its competitive capacity (Minchin, 2008; Sousa et al., 2008b). In 1989, this species was found in the estuary section of the Douro (Nagel, 1989) and Minho rivers (Araujo et al., 1993). Since then, $C$. fluminea has spread through the Minho River and has increased its presence throughout the whole estuary, establishing itself as the dominant organism in the benthic community and becoming a key species in the food web of this ecosystem (Sousa et al., 2008c). In the Lima River, on a 40-km adjacent estuarine area, this clam was first reported in 2002 (13 years later than in Minho), with density numbers (near $60 \mathrm{ind} / \mathrm{m}^{2}$ ) much lower than those from Minho (Sousa, 2003). Some indications of the drastic differences in the densities of $C$. fluminea between Minho and Lima estuaries were given by Sousa et al. (2006). Thus, although these two adjacent estuaries share similar hydrological and geological characteristics, the lapse of time in the introduction of $C$. fluminea (12 years) may indicate differences between an early introduction of C. fluminea in Minho and an ongoing colonisation of this invasive species in Lima. A relatively recent study (Sousa et al., 2007a) also showed phenotypical differences and the distinct evolution of invasive and dispersal patterns between C. fluminea populations from both estuaries, 
with results showing a much more contained behaviour in Lima. It is possible that this recent colonisation is being delayed by a high mortality of juveniles or low sexual fecundity (Sakai et al., 2001). Moreover, there is some evidence of high contamination in Lima by heavy metals (Almeida et al., 2011), which may be delaying a stronger $C$. fluminea settlement by favouring the native, more adapted benthic species, regardless of $C$. fluminea's opportunistic behaviour.
The main goal of this study was to assess the effects of the invasive clam C. fluminea on the macrofauna community and the most representative macrobenthic species from Minho and Lima's freshwater areas of these two estuaries. Keeping in mind that there is a relatively long gap of time in the introduction process of this invasive species in each one of the two studied estuaries, we tested whether the impact of $C$. fluminea on the main associated benthic macrofauna dif-

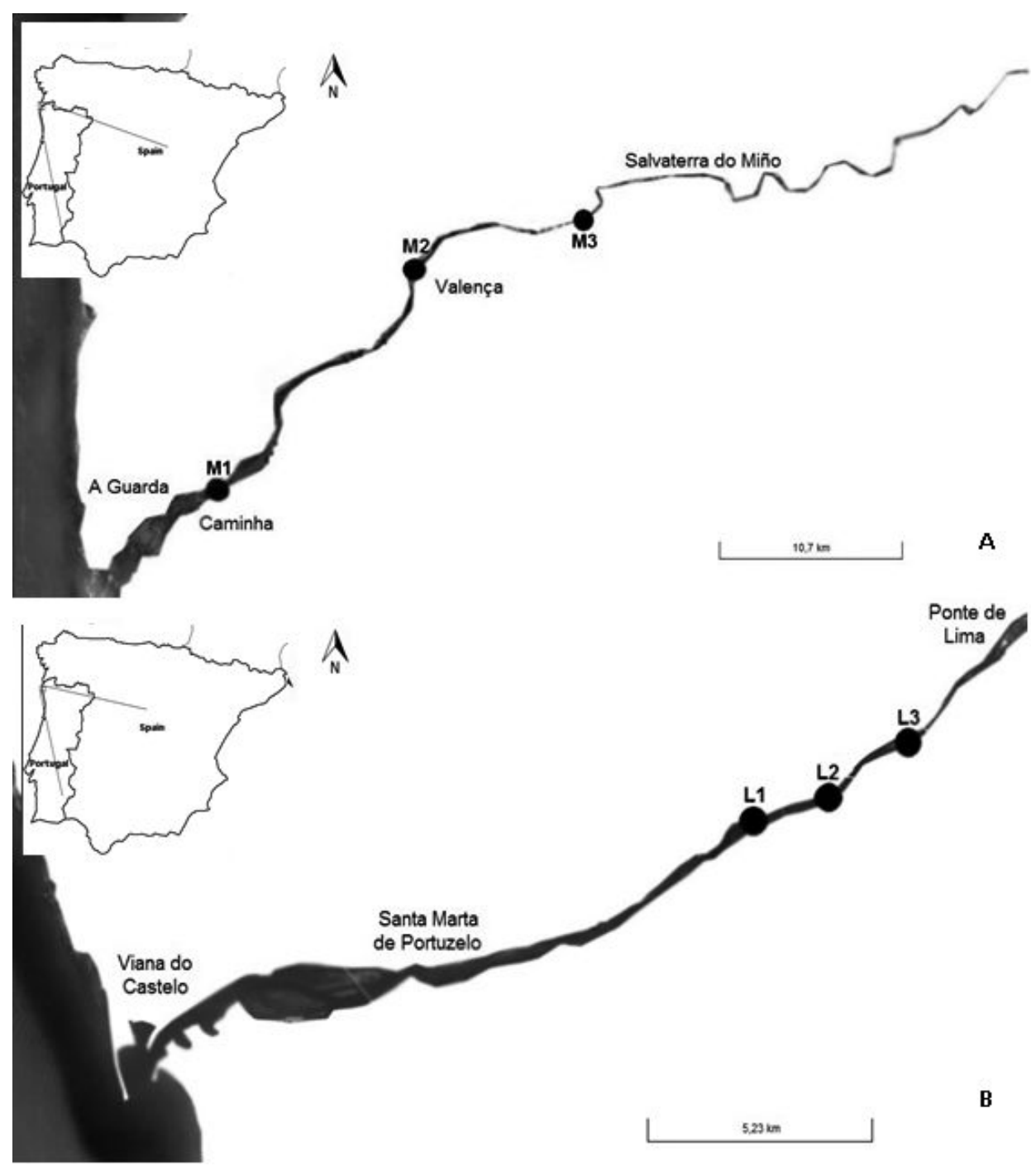

Figure 1. Sampling locations in the freshwater estuary sections (Portugal): A. River Minho estuary; B. Lima River estuary. Locations (1: downstream, 2: midstream and 3: upstream): Minho 1 (M1), Minho 2 (M2), Minho 3 (M3), Lima 1 (L1), Lima 2 (L2), Lima 3 (L3). Localidades de muestreos en las secciones dulceacuícolas de los estuarios (Portugal): A. Estuario del río Miño; B. Estuario del río Lima. Localizaciones (1: río abajo, 2: río medio y 3: río arriba): Miño 1 (M1), Miño 2 (M2), Miño 3 (M3), Lima 1 (L1), Lima 2 (L2), Lima 3 (L3). 
fered between the two estuaries. We used conventional biodiversity indices (species richness, density, Shannon and Pielou indices) to assess the macroinvertebrate community and to determine the ecological differences between the populations from the two estuaries, where introduction timing of the NIS should play an important role. Finally, we tried to assess the present status of $C$. fluminea in the Lima estuary.

\section{MATERIAL AND METHODS}

\section{Study area and sampling strategy}

The Minho River expands throughout approximately 380 km (Fig. 1A), showing a NNE-SSW orientation to the ocean. The influence of the spring tides spreads $40 \mathrm{~km}$ upstream. The Lima River is approximately $108 \mathrm{~km}$ long (Fig. 1B) and drains ENE-WSW to the Atlantic Ocean. The influence of the spring tide extends approximately $20 \mathrm{~km}$ upstream, also increasing the width of this river. Anthropogenic changes, such as port structures as well as waste drainage and dredging works, are common to both rivers (Sousa et $a l ., 2005)$. This study was conducted in the freshwater intertidal estuary section (from here on referred to simply as estuary) of both the Minho and Lima estuaries (NW of the Iberian Peninsula) because $C$. fluminea appears to thrive in these locations (see Sousa, 2003; Sousa et al., 2005). At each estuary, three locations were chosen and numerated from downstream (1), midstream (2), to upstream (3), from here on referred to as locations L1, L2, L3 for Lima, and M1, M2, M3 for Minho (Fig. 1). In each location, sediment samples for benthic biological characterisation ( $n=4$ replicates) were collected in four transects that were perpendicular to the river path and parallel to each other (separated by $5 \mathrm{~m}$ ). Samples were collected on a monthly basis during low tide between February to April 2012 with a $13.5 \mathrm{~cm}$ diameter PVC corer buried $20 \mathrm{~cm}$ deep into the substratum. All samples were placed in individual bags, adding $4 \%$ formaldehyde and rose Bengal to stain organisms. In the laboratory, samples were washed and sieved through a $0.5-\mathrm{mm}$ mesh, and the retained macrofauna was identified to the lowest possible taxa.

\section{Data analysis}

Total macrofaunal abundance (i.e., density: individuals $/ \mathrm{m}^{2}$ ), species richness (number of species), and Shannon and Pielou diversity indices were used as the main benthic community descriptors. SIMPER analyses were used to calculate the contribution (\%) of each species to the overall benthic community in each location (Clarke \& Gorley, 2001). All of the gastropods species found in this study were grouped to facilitate the analysis as one common population due to their individual sporadic appearances (see Supplementary Table S1, available at www.limnetica.net/internet).

Differences in densities, number of species, abundance of the main representative species and diversity indices were analysed using a 2-factor analysis of variance (ANOVA). Estuaries (2 levels: Minho and Lima) and locations (3 levels: down, middle and upstream) were used as fixed factors. The differences of the benthic descriptors over time (3 levels: February, March, and April) were previously tested with a 3-way ANOVA and were deemed not significant $\left(F_{1,62}=2.7961\right.$; $p>0.05)$; as a result, time was pooled in each location $(n=12)$. Before the analysis, the homogeneity of variances was evaluated with Cochran's test (Winer et al., 1991), and when necessary, data were transformed logarithmically (see Tables). A posteriori, multiple comparisons were conducted using Student-Newman-Keul's (SNK) tests to identify those factors that differed significantly ( $\alpha=0.05)$.

Regression-based techniques were also used, particularly for the analysis of relationships involving $C$. fluminea. For cases exhibiting curvature and where assumptions of simple linear regression were violated, generalised linear models (GLM) with appropriate error structures were used (Poisson error structures and log-link functions). The proportional increase in explained deviance (pseudo- $\mathrm{R}^{2}\left(\beta_{1}\right)=($ Null deviance - Residual Deviance)/Null deviance*100) was used to evaluate each model fit (Dobson, 
2002). Homogeneity of variance was evaluated by plotting residual vs predicted values, and normality was assessed via normal probability plots and Shapiro-Wilk tests on residuals. All of the analyses were fitted in R 3.0.1 (R Development Core Team, 2012).

\section{RESULTS}

\section{Macrofauna community characteristics}

A total of 901 individuals belonging to 13 species were collected at Minho estuary, and 1046 indi-
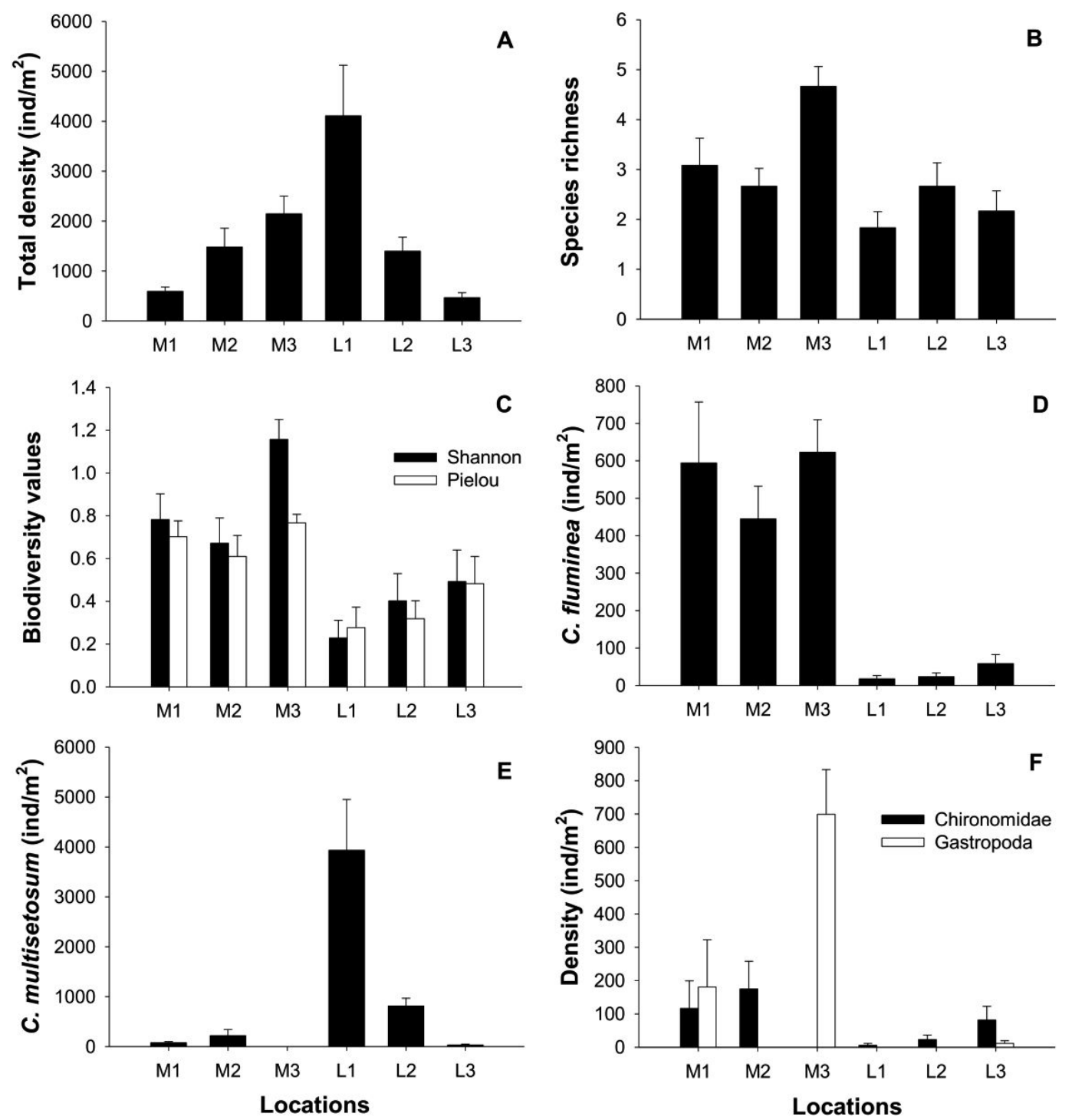

Figure 2. Mean ( \pm SE) values across all locations (M1, M2, M3, L1, L2 and L3): A. Total density (ind/ $\mathrm{m}^{2}$ ); B. Species richness (S); C. biodiversity indices, Shannon $\left(\mathrm{H}^{\prime}\right)$ and Pielou $\left(\mathrm{J}^{\prime}\right)$, D. Density of Corbicula fluminea (ind/ $\left.\mathrm{m}^{2}\right)$, E. Density of Corophium multisetosum (ind $/ \mathrm{m}^{2}$ ), and F. Density of Gastropoda and Chironomidae (ind $/ \mathrm{m}^{2}$ ) in Minho (M) and Lima (L) across all the locations (1: downstream, 2: midstream and 3: upstream). Valores medios $( \pm D E)$ A. Densidad (ind $\left./ \mathrm{m}^{2}\right)$; B. Riqueza de especies (S); C. índices de biodiversidad, Shannon $\left(H^{\prime}\right)$ y Pielou $\left(J^{\prime}\right)$, D. abundancia de Corbicula fluminea (ind/ $\left.m^{2}\right)$, E. abundancia de Corophium multisetosum (ind $/ \mathrm{m}^{2}$ ), y F. abundancia de Gasteropoda y Chironomidae (ind/ $\mathrm{m}^{2}$ ) en Miño (M) y Lima (L) en todas las localidades (1: río abajo, 2: río medio y 3: río arriba). 
viduals belonging to 9 species were collected at Lima estuary (Table S1). The total densities of the two estuaries over the three months showed a maximum value at $\mathrm{L} 1\left(4143 \mathrm{ind} / \mathrm{m}^{2}\right)$ and a minimum value at L3 (466 ind $/ \mathrm{m}^{2}$ ). In Minho, the highest value was recorded at M3 (2145 ind $\left./ \mathrm{m}^{2}\right)$ and the lowest was recorded at M1 (595 ind $\left./ \mathrm{m}^{2}\right)$. Macrofaunal abundance was not significantly different between the two estuaries $(p>0.05$; Table 1). However, this pattern changed across locations (Estuary $\times$ Location; $p<0.001$ ). Density downstream was significantly higher in Lima than in Minho (M1 $<$ L1; SNK test, $p<0.01)$ and significantly higher upstream in Minho than in Lima (L3 < M3; SNK tests, $p<0.05$ ) (see Table 1). Macrofauna density in Lima increased significantly from downstream to upstream locations (L1 = L2 > L3; SNK test, $p<0.001$ ), and in Minho, it increased in the opposite direction (Fig. 2A), although these patterns had no significant values (SNK test, $p>0.05$ ) (Table 1). The number of species (S) registered for Minho were (from downstream to upstream) M1:7, 0, 3 \pm 2 ;

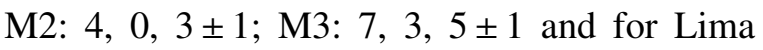
were L1: 4, 0, $2 \pm 1$; L2: 5, 0, $2 \pm 2$ and L3: 4, 0, $2 \pm 1$ (Location: highest, lowest and mean \pm SD values, respectively) (see Table S1). Species richness was significantly higher in Minho than in Lima ( $p<0.001$; Table 1$)$. This pattern changed across locations (Estuary $\times$ Location; $p<0.05$ ). Thus, species richness was significantly higher in Minho than Lima upstream (M3 $>$ L3; SNK test, $p<0.01)$ and downstream (M1 > L1; SNK test, $p<0.05$ ) (Table 1 and Fig. 2B). Species richness in Minho decreased significantly from upstream to downstream $(\mathrm{M} 1=\mathrm{M} 2<\mathrm{M} 3$; SNK test, $p<0.01$; Fig. 2B). There were no significant differences among locations in Lima (SNK test, $p>0.05)$. Both diversity indices $\left(\mathrm{H}^{\prime}\right.$ and $\left.\mathrm{J}^{\prime}\right)$ were significantly higher in Minho than in Lima (Table 1, Fig. 2C). The $\mathrm{H}^{\prime}$ index was always significantly higher upstream in both estuaries (SNK test, $p<0.05$; Table 1 ,), and no significant differences were found for $\mathbf{J}^{\prime}$ index (Table 1).

C. Aluminea was the most abundant species in Minho (SIMPER, M1: $77.23 \%$, M2: $44.95 \%$,

Table 1. Summary of analysis of variance for the benthic macroinvertebrate community: total macrofauna (Density, ind $\left./ \mathrm{m}^{2}\right)$, number of species $(\mathrm{S})$, Shannon $\left(\mathrm{H}^{\prime}\right)$ and Pielou $\left(\mathrm{J}^{\prime}\right)$ biodiversity indices. Estuaries (Es, M: Minho and L: Lima) and Locations (Lo, 1: downstream; 2: midstream; 3: upstream) are fixed factors. Significant levels ( $p$ ) are shown in Italics. Resumen del análisis de la varianza para la comunidad de macroinvertebrados bentónicos: abundancia total de la macrofauna (ind/ $\left.\mathrm{m}^{2}\right)$, número de especies $(S)$, índices de biodiversidad: Shannon $\left(H^{\prime}\right)$ y Pielou $\left(J^{\prime}\right)$. Estuarios (Es, M: Miño y L: Lima) y Localidades (Lo, 1: río abajo, 2: río medio y 3: río arriba) son factores fijos. El nivel de significancia (p) se muestra en cursiva.

\begin{tabular}{|c|c|c|c|c|c|c|c|}
\hline Variables & Source & df & MS & $\mathrm{F}$ & $p$ & SNK tests & \\
\hline \multirow[t]{4}{*}{ Density $^{a}$} & Es & 1 & 1569183 & 0.45 & 0.504 & & \\
\hline & Lo & 2 & & 4.63 & 0.013 & Lo: & $3=2<1 *$ \\
\hline & Es $\times$ Lo & 2 & 28684561 & 8.25 & $<0.001$ & EsXLo: & $\mathrm{M} 1<\mathrm{L} 1 * * ; \mathrm{L} 3<\mathrm{M} 3 *$ \\
\hline & RES & 66 & 3476204 & & & LoXEs: & $\mathrm{L} 3=\mathrm{L} 2<\mathrm{L} 1 * *$ \\
\hline \multirow[t]{4}{*}{$\mathrm{S}$} & Es & 1 & 28.1 & 13.24 & 0.001 & Es: & $\mathrm{L}<\mathrm{M}^{* * *}$ \\
\hline & Lo & 2 & 6.1 & 2.87 & 0.064 & & \\
\hline & Es $\times$ Lo & 2 & 9.4 & 4.41 & 0.016 & EsXLo: & $\mathrm{L} 1<\mathrm{M} 1 * ; \mathrm{L} 3<\mathrm{M} 3 * *$ \\
\hline & RES & 66 & 2.1 & & & LoXEs: & $\mathrm{M} 1=\mathrm{M} 2<\mathrm{M} 3 * *$ \\
\hline \multirow[t]{4}{*}{$\mathrm{H}^{\prime}$} & Es & 1 & 4.4 & 27.06 & $<0.001$ & Es: & $\mathrm{L}<\mathrm{M}^{* * *}$ \\
\hline & Lo & 2 & 0.74 & 4.56 & 0.014 & & $1=2<3 *$ \\
\hline & Es $\times$ Lo & 2 & 0.25 & 1.53 & 0.224 & & \\
\hline & RES & 66 & 0.16 & & & & \\
\hline \multirow[t]{4}{*}{$\mathrm{J}^{\prime}$} & Es & 1 & 2.0 & 20.32 & $<0.001$ & Es: & $\mathrm{L}<\mathrm{M}^{* * *}$ \\
\hline & Lo & 2 & 0.18 & 1.81 & 0.171 & & \\
\hline & Es $\times$ Lo & 2 & 0.04 & 0.38 & 0.682 & & \\
\hline & RES & 66 & 0.1 & & & & \\
\hline
\end{tabular}

${ }^{a} \ln (x+1)$ transformed data. SNK test significant levels $p<0.05(*) ; p<0.01(* *) ; p<0.001$ (***). df: degrees of freedom. MS: Mean squares. SNK: Student-Newman-Keul's post hoc tests. RES: Residuals. 
M3: $47.88 \%$ ) (Supplementary Table S2). The mean density values were always higher than $400 \mathrm{ind} / \mathrm{m}^{2}$ in all locations (Fig. 2D), and the highest value was found at M3 (623 ind $/ \mathrm{m}^{2}$, Table S1). In contrast, the population in Lima showed much lower densities (SIMPER, L1: $0.52 \%$, L2: $0.51 \%$, L3: $2.54 \%$; Table S2). The highest density was registered at L3 (58 ind $/ \mathrm{m}^{2}$; Fig. 2D). The ANOVA analysis showed that the density of the invasive $C$. fluminea was significantly higher $(p<0.001)$ in Minho than in Lima (Table 2). The crustacean amphipod Corophium multisetosum was the predominant species in Lima (SIMPER, L1: 92.72\%, L2: $91.8 \%$, L3: $8.6 \%$; Table S2) with the highest value being registered in L1 (3933 ind $/ \mathrm{m}^{2}$; Table S1). In the midstream Minho location (M2), this amphipod showed a meaningful presence (676 ind $/ \mathrm{m}^{2}$, Table S1) (SIMPER, M1: 1.64\%, M2: $26.91 \%$, M3: not present; Table S2). C. multisetosum was significantly higher in Lima than in Minho (Table $2, p<0.001)$. There were significant diffe- rences across locations in both estuaries (Table 2, $p<0.001)$. Thus, $C$. multisetosum was always significantly lower at upstream locations in Minho and Lima (Fig. 2E).

As for gastropods, the lowest mean density was recorded at $\mathrm{L} 1$ (12 ind $\left./ \mathrm{m}^{2}\right)$, and the highest mean density was recorded at M3 (699 ind $/ \mathrm{m}^{2}$; Table S1) (SIMPER, M3: 24.75\%; Table S2). Gastropoda density was significantly higher in Minho than in Lima $(p<0.001)$ (Table 2), with a very low presence at Lima (Fig. 2F). However, this pattern changed across locations (Estuary $\times$ Location, $p<0.001$; Table 2). Thus, Gastropoda was significantly more present in Minho upstream (L3 $\ll$ M3; SNK test, $p<0.01$ ) and downstream (L1 «M1; SNK test, $p<0.01$ ), and no significant differences were found at midstream locations (Fig. 2F). The distribution of Gastropoda in Minho varied significantly across locations $(\mathrm{M} 1=\mathrm{M} 2<\mathrm{M} 3$; SNK test, $p<0.01$ ), but no significant differences were found in Lima ( $p>0.05$; SNK test, Fig. 2F).

Table 2. Summary of analysis of variance of the effect of Estuaries (Es; M: Minho and L: Lima) and Locations (Lo; 1: downstream; 2: midstream; 3: upstream) on the benthic macroinvertebrate community: density (ind $/ \mathrm{m}^{2}$ ) of C. fluminea, C. multisetosum, Gastropoda and Chironomidae. Significant levels $(p)$ are shown in italics. Resumen del análisis de la varianza de los efectos de Estuarios (Es; M: Miño y L: Lima) y Localidades (Lo; 1: río abajo, 2: río medio y 3: río arriba) sobre la comunidad de macroinvertebrados bentónicos: abundancia $\left(\right.$ ind $\left./ \mathrm{m}^{2}\right)$ de C. fluminea, C. multisetosum, Gasteropoda y Chironomidae. El nivel de significancia (p) se muestra en cursiva.

\begin{tabular}{|c|c|c|c|c|c|c|c|}
\hline Main species & Source & df & MS & $\mathrm{F}$ & $p$ & SNK & \\
\hline \multirow[t]{4}{*}{ C. flumine $a^{a}$} & Es & 1 & 331.0 & 78.62 & $<0.001$ & Es: & $\mathrm{L}<\mathrm{M}^{* * *}$ \\
\hline & Lo & 2 & 6.1 & 1.45 & 0.243 & & \\
\hline & Es $\times$ Lo & 2 & 1.1 & 0.26 & 0.775 & & \\
\hline & RES & 66 & 4.2 & & & & \\
\hline \multirow[t]{4}{*}{ C. multisetosum ${ }^{a}$} & Es & 1 & 117.5 & 17.99 & $<0.001$ & Es: & $\mathrm{M}<\mathrm{L} * * *$ \\
\hline & Lo & 2 & 132.0 & 20.22 & $<0.001$ & Lo: & $1=2<3 * * *$ \\
\hline & Es $\times$ Lo & 2 & 4.4 & 0.68 & 0.512 & & \\
\hline & RES & 66 & 6.5 & & & & \\
\hline \multirow[t]{5}{*}{ Gastropoda } & Es & 1 & 1507881 & 19.75 & $<0.001$ & Es: & $\mathrm{L}<\mathrm{M}^{* * *}$ \\
\hline & Lo & 2 & 819313 & 10.73 & $<0.001$ & Lo: & $1=2<3 * * *$ \\
\hline & Es $\times$ Lo & 2 & 762532 & 9.99 & $<0.001$ & EsXLo: & $\mathrm{L} 1<\mathrm{M} 1 * *$ \\
\hline & & & & & & & $\mathrm{L} 3<\mathrm{M} 3 * *$ \\
\hline & RES & 66 & 76360 & & & LoXEs: & $\mathrm{M} 1=\mathrm{M} 2<\mathrm{M} 3 * *$ \\
\hline \multirow[t]{4}{*}{ Chironomidae $^{b}$} & Es & 1 & 0.638 & 0.14 & 0.711 & & \\
\hline & Lo & 2 & 10.2808 & 2.23 & 0.116 & & \\
\hline & Es $\times$ Lo & 2 & 18.5 & 4.01 & 0.023 & EsXLo: & $\mathrm{M} 3<\mathrm{L} 3 *$ \\
\hline & RES & 66 & 4.6 & & & LoXEs: & $\mathrm{M} 3<\mathrm{M} 2<\mathrm{M} 1 * *$ \\
\hline
\end{tabular}

${ }^{a} \ln (x+1)$ transformed data. ${ }^{b} \ln (x+0.001)$ transformed data. SNK test significant levels $p<0.05(*) ; p<0.01(* *) ; p<0.001$ (***). df: degrees of freedom. MS: Mean squares. SNK: Student-Newman-Keul's post hoc tests. RES: Residuals. 
The larvae from the Chironomidae family (main taxa present from Order Diptera) registered the highest density values at M2, $175 \mathrm{ind} / \mathrm{m}^{2}$ (Table S1) (SIMPER, M2: $9.1 \%$, L2: $0.51 \%$ and L3: $10.18 \%$; Table S2). The density of the Chironomidae family was not significantly different between the two estuaries (Table 2; $p>0.05)$. However, this pattern changed significantly across locations (Estuary $\times$ Location; $p<0.05)$. In Minho, the Chironomidae family was significantly higher from upstream to downstream (M1 < M2 «M3, SNK test; Table 2), and no significant differences were found in Lima (Fig. 2F).

\section{Regression-based models}

The diversity index $\mathrm{H}^{\prime}$ was found to be highly correlated (Spearman correlation) with species richness $(R=0.872)$ and $\mathrm{J}^{\prime}(R=0.910)$. Species richness was also strongly correlated with $\mathrm{J}^{\prime}$ $(R=0.610)$. There was no need to use the three variables for graphical designs; therefore, only $\mathrm{H}^{\prime}$ was chosen to represent biodiversity descriptors (for all the relationships, see Supplementary Table S3). We also included the relationship C. fluminea-C. multisetosum in this analysis because of the importance of these two species (in terms of abundance) in our study.

The effect of $C$. fluminea on benthic species and main benthic descriptors is easiest to visualise with bivariate scatterplots (Fig. 3). For all variables, two different groups representing each estuary were charted showing clear distinct patterns (see Fig. 3). The $C$. fluminea- $C$. multisetosum relationship (Fig. 3A) showed a significant and negative relationship $(p<0.001)$, although rather weak $\left(\beta_{1}=0.13\right.$, Table 3$)$. The relationships of $C$. fluminea with Gastropoda $\left(\beta_{1}=0.33 ; p<0.001\right.$, Table 3, Fig. 3B) species richness $\left(\beta_{1}=0.2 ; p<0.001\right.$, Table 3$)$ and the $\mathrm{H}^{\prime}$ diversity index $\left(\beta_{1}=0.22 ; p<0.001\right.$, Fig. 3C) were all significant and positive. The relationship with macrofauna density was also significant and positive $(p<0.001)$, although rather weak $\left(\beta_{1}=0.1\right.$, Table 3$)$.

C. multisetosum is the most abundant species in Lima, and Gastropoda is a very well-

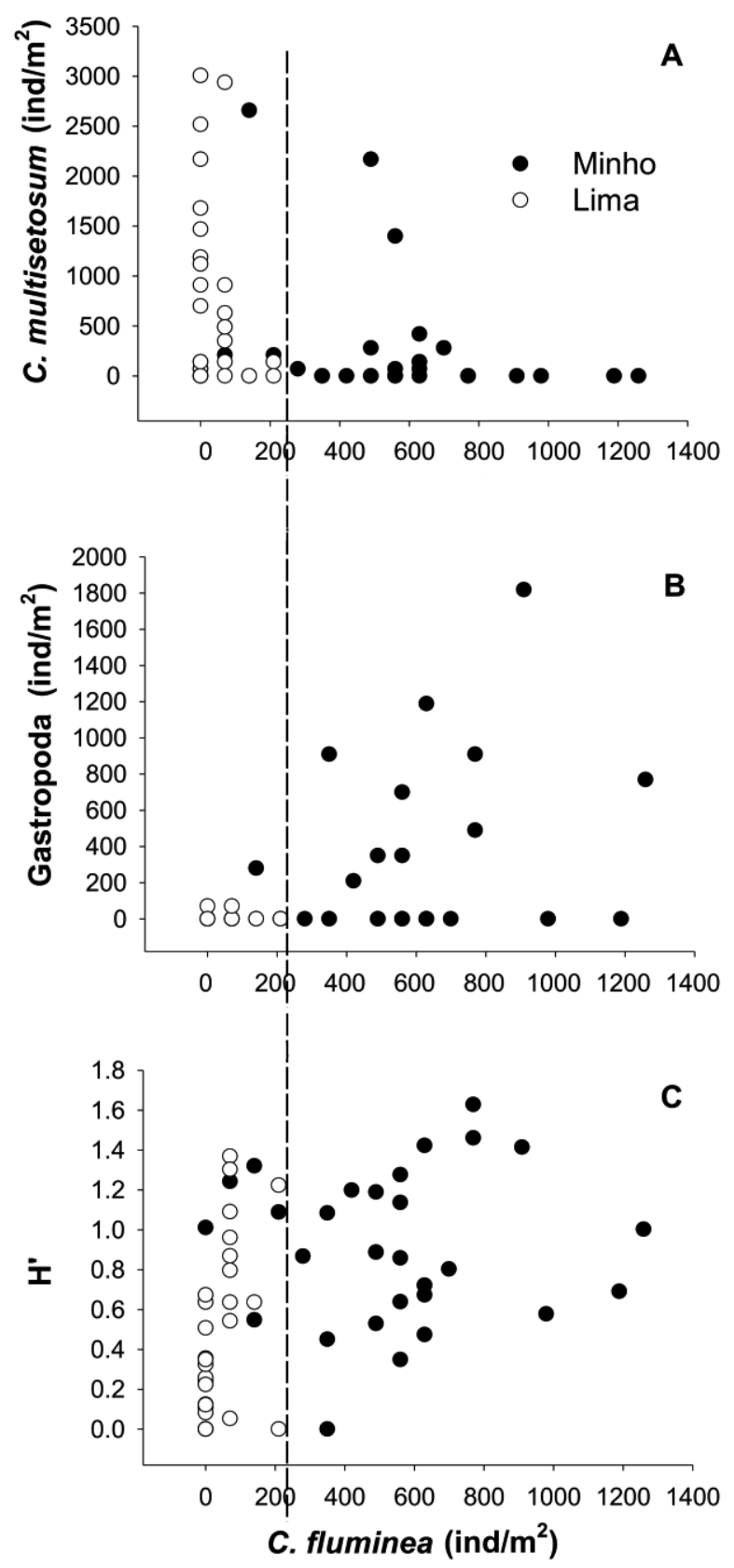

Figure 3. Bivariate scatterplots of mean values in Minho (M) and Lima (L): A. C. multisetosum vs C. fluminea; B. Gastropoda vs $C$. fluminea; $\mathrm{C}$. $\mathrm{H}^{\prime}$ vs $C$. fluminea. The range of data (individuals $/ \mathrm{m}^{2}$ ) from each estuary is depicted using a dashed line (hypothetical threshold density of $C$. fluminea $\approx 200-250$ molluscs $\left./ \mathrm{m}^{2}\right)$. Diagrama de dispersión de los valores medios en Miño $(M)$ y Lima $(L)$ : A. C. multisetosum vs C. fluminea; B. Gastropoda vs C. fluminea; $C$. $H^{\prime}$ vs C. fluminea. El rango de datos (individuos $/ \mathrm{m}^{2}$ ) de cada estuario está descrito usando un línea discontinua (umbral de densidad hipotético de $\mathrm{C}$. fluminea $\approx 200-250$ moluscos $/ \mathrm{m}^{2}$ ). 
represented group in Minho (Table S2). Therefore, we checked the relationship between C. multisetosum and the Gastropoda group and their relationships with the main community descriptors to compare their effect relative to the $C$. fluminea effect on associated macrofauna (Fig. 4, Table 3). The relationship between $C$. multisetosum and Gastropoda was strong, very significant and negative $\left(\beta_{1}=0.40\right.$; $p<0.001$, Fig. 4A). Furthermore, Gastropoda showed strong and positive relationships with $\mathrm{H}^{\prime}\left(\beta_{1}=0.26 ; p<0.001\right)$ and species richness $\left(\beta_{1}=0.35 ; p<0.001\right.$, Table 3 , Fig. 4B). $C$. multisetosum and total density showed a positive relationship $\left(\beta_{1}=0.23 ; p<0.001\right.$, Fig. $\left.4 \mathrm{C}\right)$.

\section{DISCUSSION}

Our results highlighted the key role that invasive species play in defining associated benthic macrofauna communities within freshwater softsediment ecosystems (Crooks, 2002; Sousa et al., 2009). We hypothesised that the presence of the highly invasive Asian clam, C. fluminea, would have a negative impact on the benthic community and biodiversity in freshwater locations of these two Portuguese estuaries. Most of the studies to date showed a negative effect of this invasive species on the associated macrofauna community (especially to other bivalves) and even an impoverishment of the sediment quality of the aquatic ecosystems (Phelps, 1994; Hakenkamp et al. 2001; McMahon, 2002; Nguyen \& Pauw, 2002). However, other studies (e.g., Crooks, 2002; Ilarri et al., 2012; the present study) have reported an increase in macroinvertebrates' density, biomass and diversity, particularly with positive responses of faunistical groups, such as Insecta, Crustacea and Gastropoda, in the presence of $C$. fluminea. Crooks (2002) argued that the introduction of an invasive species can have positive effects on community descriptors, such as abundance and/or biodiversity, if the introduced species increased the level of complexity or the heterogeneity of a habitat, turning the substrate into a more accessible habitat to benthic invertebrates and also providing refuge. This could have a

Table 3. ANOVA output for the generalised linear models (GLMs) predicted for the significant relationships between the main benthic community species (ind $/ \mathrm{m}^{2}$ ) and the main benthic community descriptors. Resultados del ANOVA para los modelos lineares generalizados (GLMs) para las relaciones significativas entre la comunidad de especies bentónicas (ind/ $\mathrm{m}^{2}$ ) y los principales descriptores de la comunidad bentónica.

\begin{tabular}{|c|c|c|c|c|c|c|c|}
\hline \multirow[b]{2}{*}{ Response variables $(y)$} & \multirow[b]{2}{*}{ Predictor variables $(x)$} & \multicolumn{6}{|c|}{$\begin{array}{l}\text { Generalised linear models ANOVA }\left(\mathrm{Chi}^{2}\right) \\
\text { Model: } \log (y)=\beta_{0}+\beta_{1} x_{i}\end{array}$} \\
\hline & & Df & Dev. & Res. Df & Res. Dev. F & $\beta_{1}$ & $\chi^{2}$ \\
\hline \multirow[t]{2}{*}{ C. multisetosum } & Intercept $\left(\beta_{0}\right)$ & & & 63 & 67532 & & \\
\hline & C. fluminea & 1 & 8668 & 62 & 58864 & 0.13 & $<0.001$ \\
\hline \multirow[t]{2}{*}{ Gastropoda } & Intercept $\left(\beta_{0}\right)$ & & & 63 & 30565 & & \\
\hline & C. fluminea & 1 & 10184 & 62 & 20381 & 0.33 & $<0.001$ \\
\hline \multirow[t]{2}{*}{ Density } & Intercept $\left(\beta_{0}\right)$ & & & 63 & 60362 & & \\
\hline & C. fluminea & 1 & 5408 & 62 & 54954 & 0.1 & $<0.001$ \\
\hline \multirow[t]{2}{*}{$\mathrm{H}^{\prime}$} & Intercept $\left(\beta_{0}\right)$ & & & 63 & 14.655 & & \\
\hline & C. fluminea & 1 & 3.270 & 62 & 11.385 & 0.22 & $<0.001$ \\
\hline \multirow[t]{2}{*}{ Gastropoda } & Intercept $\left(\beta_{0}\right)$ & & & 63 & 30565 & & \\
\hline & C. multisetosum & 1 & 12292 & 62 & 18272 & 0.40 & $<0.001$ \\
\hline \multirow[t]{2}{*}{$\mathrm{H}^{\prime}$} & Intercept $\left(\beta_{0}\right)$ & & & 63 & 14.655 & & \\
\hline & Gastropoda & 1 & 3.758 & 62 & 10.897 & 0.26 & $<0.001$ \\
\hline \multirow[t]{2}{*}{ Density } & Intercept $\left(\beta_{0}\right)$ & & & 63 & 60362 & & \\
\hline & C. multisetosum & 1 & 15415 & 62 & 44947 & 0.26 & $<0.001$ \\
\hline
\end{tabular}

Df: Degrees of freedom, Dev: Deviance, Res Df: Residual degrees of freedom, Res. Dev. F: Residual Deviance F, $\chi^{2}$ : Chi squared test value, $\beta_{1}$ : Pseudo- $\mathrm{R}^{2}$ (The proportional increase in explained deviance $=($ Null deviance - Residual Deviance $) /$ Null deviance*100) was used to evaluate each model fit $($ Dobson, 2002). 
stronger effect on soft-sediment localities, such as Lima and Minho, that are homogenised by dredging and other anthropogenic activities (Sousa et al., 2005; Costa-Dias et al., 2010a). Furthermore, bivalves such as $C$. fluminea, can act as ecosystem engineers (sensu Jones et al. 1994), altering the levels of sediment water, dissolved oxygen and nutrient recycling through bioturbation, thus improving habitat quality (Sousa et al., 2008b). In this study, C. fluminea was shown to be associated with an increase in macrofauna density and biodiversity descriptors, such as species richness and Shannon and Pielou indices. Furthermore, the density of $C$. fluminea was highly related to the density of another faunistical group, the Gastropoda order. Nevertheless, the main Crustacean species, the amphipod $C$. multisetosum, was negatively influenced by the presence of $C$. fluminea.

The effect of $C$. fluminea on the macrofauna community, including Gastropoda, was much more noticeable in the Minho estuary, where the invasive Asian clam was first established. Currently, it is still the most abundant species (Sousa et al., 2005; Sousa et al., 2008c). In Lima though, the positive effects of $C$. $f l u$ minea on total macrofauna density, species richness and diversity were entirely negated mainly due to the low $C$. fluminea densities and the high presence of the native crustacean C. multisetosum. As previously mentioned, the presence of this invasive species in Lima (first reported in 2002 by Sousa, 2003) is much more recent than in Minho (first reported in 1989 by Araujo et al., 1993), and the densities are still low compared to the nearby Minho estuary. Thus, the relationships between $C$. fluminea- $C$. multisetosum, and between Gastropoda-C. multisetosum were found to be negative in Lima. The bivariate scatterplots clearly established two starkly contrasting groups representing locations in each estuary. The scatterplots show clear distinct patterns in the main relationships between the benthic community descriptors. The range of data from each estuary seems to be more noticeable from a $C$. fluminea density of approximately $200-250 \mathrm{ind} / \mathrm{m}^{2}$ (see Fig. 3). This result might indicate a threshold from which
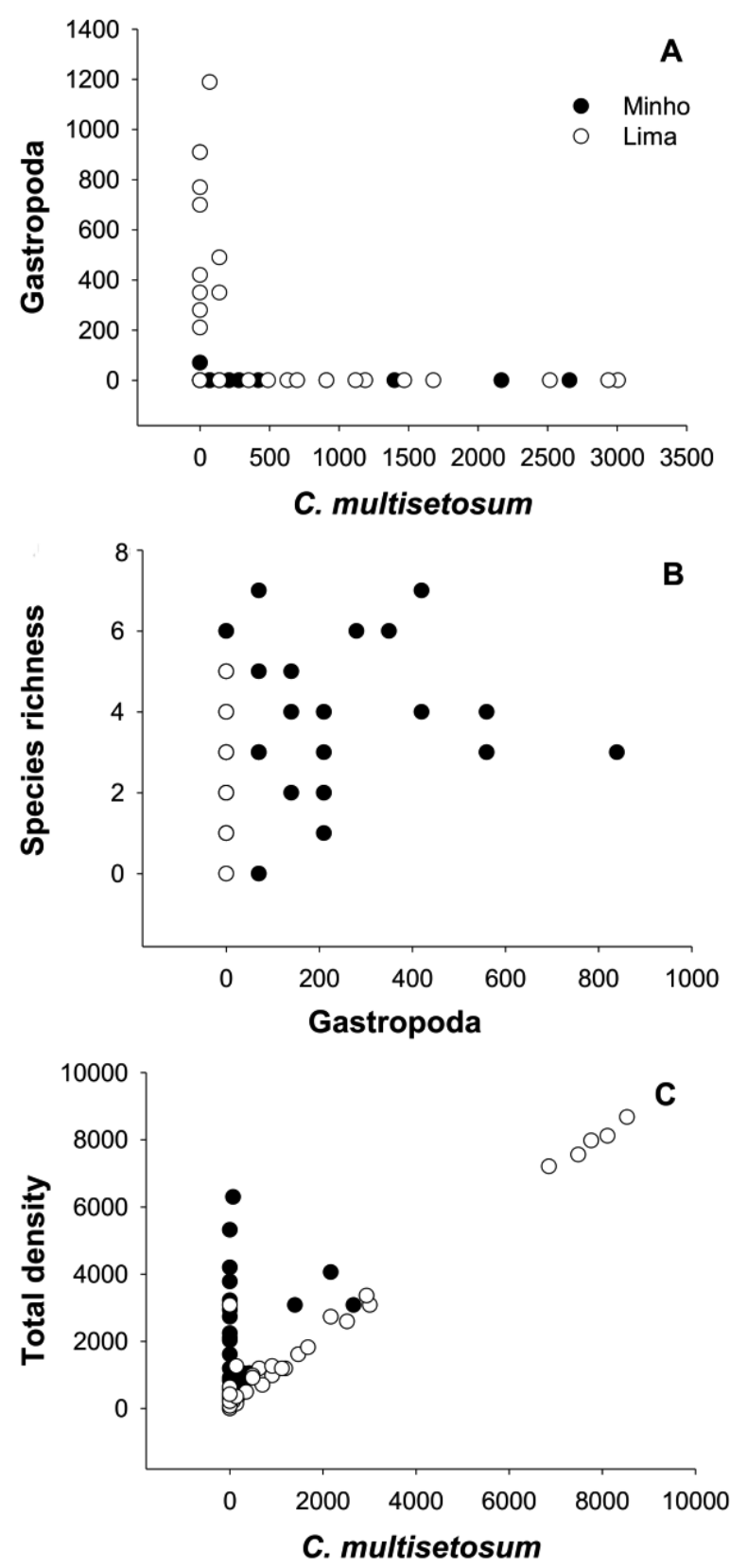

Figure 4. Bivariate scatterplots of mean values in Minho (M) and Lima (L): A. C. multisetosum vs Gastropoda; B. S vs Gastropoda; and C. C. multisetosum vs total density. Units are individuals $/ \mathrm{m}^{2}$. Diagrama de dispersión de los valores medios en Miño $(M)$ y Lima $(L)$ : A. C. multisetosum vs Gastropoda; $B$. $S$ vs Gastropoda; y C. C. multisetosum vs abundancia total. Unidades: individuos $/ \mathrm{m}^{2}$.

C. fluminea begins to have a significant effect on other faunistical groups. This feasible threshold value may also indicate the end of the initial inva- 
sive stages of $C$. fluminea and the start of its exponential growth (Sakai et al., 2001; Crooks, 2005; see also Sousa et al., 2006). However, this threshold value needs to be further tested by means of specific in situ and/or lab experiments, manipulating the numbers of the invasive species to obtain unequivocal causal relationships.

In the River Lima, C. fluminea is still confined to similar low densities already recorded more than a decade ago (Sousa, 2003; CostaDias et al., 2010b). In Lima, the lag-time phase inherent to any biological invasion should have been surpassed, and the densities of the Asian clam should have multiplied and reached levels similar to those registered in Minho in 1990 (see Araujo et al., 1993). Unfortunately, we did not record any information on the abiotic factors from Minho and Lima. However, several studies revealed that both salinity and temperature are normally accounted as the main abiotic factors that influence the distribution of $C$. fluminea in these two estuaries (Costa-Dias et al., 2010b; Franco et al., 2012; Modesto et al., 2013). Nevertheless, C. fluminea has been shown to withstand salinities up to 14 ppt (Sousa, 2008b), and in this study, this bivalve also showed no problem in playing a major role in the benthic community in downstream Minho, where salinity levels are equivalent to downstream Lima (Costa-Dias et al., 2010a; Ilarri et al., 2012).

According to several authors (Emery \& Gross, 2007; James et al., 2008), the functional traits of dominant species (e.g., feeding preferences, habitat occupation) might play a much larger role in defining the success of a specific invasion than biodiversity. For example, C. multisetosum competes directly with $C$. fluminea for soft, muddy and clayish substrate, preferentially with some quantity of organic matter (Rodrigues et al., 2011; Wijnhoven et al., 2011). In this type of substrate, C. multisetosum builds dwelling-tubes and feeds on detritus that is deposited on the substratum; meanwhile, $C$. fluminea burrows and feeds by paddling, besides filtrating the water column (Cunha et al., 2000a; Hakenkamp et al., 2001). There are several studies that show a negative relationship between amphipods and clams for functional reasons, such as habitat and food competition (Wijnhoven et al., 2011), habitat plugging and/or destruction by clams (Jensen, 1985), and suffocation, predation and/or crushing of the clam larvae by amphipods (Elmgren et al., 1986; Ejdung \& Elmgren, 1998; Ejdung et al., 2000). Furthermore, during summer, both species register massive die-offs in Southern Europe due to temperature increases (Cunha et al., 2000b; Sousa et al., 2007b). As $C$. fluminea acquires sexual maturation between 3-6 months, while $C$. multisetosum has a faster life cycle and acquires sexual maturation in only one month (Cunha et al., 2000a), these die-offs may also play a major role in redefining the benthic assemblage. It is possible that the extreme dominance of $C$. multisetosum over the rest of the associated benthic assemblage may prevent the exponential growth of the NIS ( $C$. fluminea). To our knowledge, this study is among the first to register and analyse a possible species-level cause to the lag-time phase prolongation of an invasion by $C$. fluminea, a highly successful NIS.

In this study, $C$. fluminea clearly showed its attributes as a species that can model other species in a strong fashion. The shells of the bivalve seem to create a complex three-dimensional heterogeneous habitat, which is more noticeable on otherwise soft sediment homogeneous habitats. In accordance with this observation, our results show that an increase in $C$. fluminea's density appears to be linked to higher values of biodiversity. Nevertheless, an invasion by $C$. fluminea seems to produce negative effects on specific benthic species, such as the amphipod Corophium multisetosum. We think that this species is strongly interacting with $C$. fluminea (competing for habitat and/or food, or by direct predation), hindering the progress of the invasion process, coupled with the effect of specific abiotic factors, such as temperature, salinity or sediment type. We strongly recommend that future experimental studies should be performed in the field and/or in the laboratory, manipulating the number of $C$. fluminea and also the environmental conditions. Future studies should aim to specifically assess the thresholds we suggest here and to what extent $C$. fluminea may affect other macroinvertebrate species, whether directly or indirectly. 


\section{ACKNOWLEDGEMENTS}

This work was funded by a grant from the Portuguese Foundation for Science and TechnologyFCT (PTDC/AAC-AMB/102866/2008). Funding to Iván F. Rodil was provided by an FCT postdoctoral grant (SFRH/BPD/87042/2012). The authors also thank three reviewers and Francisco Arenas for their collaboration and scientific input and William Sharkey for reviewing the language of the manuscript.

\section{REFERENCES}

ALMEIDA, C. M. P., A. P. MUCHA \& M. VASCONCELOS. 2011. Role of different salt marsh plants on metal retention in an urban estuary (Lima estuary, NW Portugal). Estuarine Coastal and Shelf Science, 91: 243-249.

ARAUJO, R., D. MORENO, N. A. RAMOS, M. NACIONAL, D. C. NATURALES \& J. G. ABASCAL. 1993. The Asiatic clam Corbicula fluminea (Müller, 1774) (Bivalvia: Corbiculidae) in Europe. American Malacological Bullettin, 10: 39-49.

CLARKE, K. \& R. GORLEY. 2001. Primer v5: User Manual/Tutorial. Primer-E-Ltd. U.K.

COSTA-DIAS, S., R. SOUSA \& C. ANTUNES. 2010a. Ecological quality assessment of the lower Lima Estuary. Marine Pollution Bulletin, 61: 234-239.

COSTA-DIAS, S., V. FREITAS, R. SOUSA \& C. ANTUNES. 2010b. Factors influencing epibenthic assemblages in the Minho Estuary (NW Iberian Peninsula). Marine Pollution Bulletin, 61: 240-246.

CROOKS, J. 2002. Characterizing ecosystem-level consequences of biological invasions?: the role of ecosystem engineers. OIKOS, 97: 153-166.

CROOKS, J. 2005. Lag times and exotic species: the ecology and management of biological invasions in slow-motion. Ecoscience, 12: 316-329.

CUNHA, M. R., J. C. SORBE \& M. H. MOREIRA. 2000a. The amphipod Corophium multisetosum (Corophiidae) in Ria de Aveiro (NW Portugal). I. Life history and aspects of reproductive biology. Marine Biology, 137: 637-650.

CUNHA, M. R., J. C. SORBE \& M. H. MOREIRA. 2000b. The amphipod Corophium multisetosum (Corophiidae) in Ria de Aveiro (NW Portugal).
II. Abundance, biomass and production. Marine Biology, 137: 651-660.

DOBSON, A. 2002. An Introduction to Generalized Linear Models. $2^{\text {nd }}$ Edition.

DRAKE, J. M. \& D. M. LODGE. 2007. Hull fouling is a risk factor for intercontinental species exchange in aquatic ecosystems. Aquatic Invasions, 2: 121-131.

EJDUNG, G. \& R. ELMGEN. 1998. Predation on newly settled bivalves by deposit-feeding amphipods: a Baltic Sea case study. Marine Ecology Progress Series, 168: 87-94.

EJDUNG, G., L. BYRÉN \& R. ELMGREN. 2000. Benthic predator-prey interactions: evidence that adult Monoporeia affinis (Amphipoda) eat postlarval Macoma balthica (Bivalvia). Journal of Experimental Marine Biology and Ecology, 253: 243251.

ELLIOT, P. \& P. ZU ERMGASSEN. 2008. The Asian clam (Corbicula fluminea) in the River Thames, London, England. Aquatic Invasions, 3: 54-60.

ELMGREN, R., A. ANKAR, B. MARTELEUR \& G. EJDUNG. 1986. Adult interference with postlarvae in soft sediments: the Pontoporeia-Macoma example. Ecology, 67: 827-836.

EMERY, S. M. \& K. L. GROSS. 2007. Dominant species identity, not community evenness, regulates invasion in experimental grassland plant communities. Ecology, 88:954-964

FOGARTY, G. \& M. FACELLI. 1999. Growth and competition of Cytisus scoparius, an invasive shrub, and Australian native shrubs. Plant Ecology, 144: 27-35.

FRANCO, J. N., F. R. CEIA, J. PATRÍCIO, V. MODESTO, J. THOMPSON, J. C. MARQUES \& J. M. NETO. 2012. Population dynamics of Corbicula fluminea (Müller, 1774) in mesohaline and oligohaline habitats: Invasion success in a Southern Europe estuary. Estuarine Coastal and Shelf Science, 112: 31-39.

GHERARDI, F. \& W. DANIELS. 2005. Agonism and shelter competition between invasive and indigenous crayfish species. Canadian Journal of Zoology, 82: 1923-1932.

HAKENKAMP, C. C., S. G. RIBBLETT \& M. A. PALMER. 2001. The impact of an introduced bivalve (Corbicula fluminea) on the benthos of a sandy stream. Freshwater Biology, 46: 491-501.

HARTOG, C. DEN, F. W. B. VAN DEN BRINK \& G. VAN DER VELDE. 1992. Why was the invasion of the river Rhine by Corophium curvispinum and 
Corbicula species so successful? Journal of Natural History, 26: 1121-1129.

HUMAN, K. G. \& D. M. GORDON. 1996. Exploitation and interference competition between the invasive Argentine ant, Linepithema humile, and native ant species. Oecologia, 105: 405-412.

ILARRI, M. I., F. FREITAS, S. COSTA-DIAS, C. ANTUNES, L. GUILHERMINO \& R. SOUSA. 2012. Associated macrozoobenthos with the invasive Asian clam Corbicula fluminea. Journal of Sea Research, 72: 113-120.

ITUARTE, C. 1994. Corbicula and Neocorbicula (Bivalvia: Corbiculidae) in the Parana, Uruguay, and Rio de la Plata basin. Nautilus, 107: 129-135.

JAMES, J. J., K. W. DAVIES, R. L. SHELEY \& Z. T. AANDERUD. 2008. Linking nitrogen partitioning and species abundance to invasion resistance in the Great Basin. Oecologia, 156: 637-648.

JENSEN, K. T. 1985. The presence of the bivalve $C e$ rastoderma edule affects migration, survival and reproduction of the amphipod Corophium volutator. Marine Ecology Progress Series, 25: 269-277.

JONES, C., J. LAWTON \& M. O. SHACHAK. 1994. Organisms as ecosystem engineers. OIKOS, 69: 373-386.

LODGE, M. 1993. Biological Invasions: Lessons for Ecology. TREE, 8: 133-137.

MACK, M. \& C. D’ANTONIO. 1998. Impacts of biological invasions on disturbance regimes. TREE, 13: 195-198.

MCMAHON, R. F. 1982. The occurrence and spread of the introduced Asiatic freshwater clam, Corbicula fluminea (Müller, 1774), in North America: 1924-1982. Nautilus, 96: 134-141.

MCMAHON, R. F. 2000. Invasive characteristics of the freshwater bivalve Corbicula fluminea. In: Nonindigenous Freshwater Organisms: Vectors, Biology and Impacts (R. Claudi \& J. Leach, eds.), pp. 315-343. Boca Raton: Lewis Publishers.

MCMAHON, R. F. 2002. Evolutionary and physiological adaptations of aquatic invasive animals: $r$ selection versus resistance. Canadian Journal of Fish Aquatic Science, 59: 1235-1244.

MINCHIN, D. 2008. Corbicula fluminea. In: Delivering Alien Invasive Especies in Europe. http://www. europe-aliens.org/speciesFactsheet.do?speciesId $=53281$

MODESTO, V., J. N. FRANCO, R. SOUSA, J. PATRÍCIO, J. C. MARQUES \& J. M. NETO. 2013. Spatial and temporal dynamics of Corbicula fluminea (Müller, 1774) in relation to environmental variables in the Mondego Estuary (Portugal). Journal of Molluscean Studies, 79: 302-309.

MOUTHON, J. 1981. Sur la présence en France et au Portugal de Corbicula (Bivalvia, Corbiculidae) originaire d' Asie [About the presence in France and Portugal of Corbicula (Bivalvia, Corbiculidae) native in Asia]. Basteria, 45: 109-116.

NAGEL, K. O. 1989. Ein weiterer Fundort von Corbicula fluminalis (Müller, 1774) (Mollusca, Bivalvia) in Portugal [A further discovery of Corbicula fluminalis (Müller, 1774) (Mollusca: Bivalvia) in Portugal]. Mitteilungen der deutschen malakozoologischen Gesellschaft, 17: 44-45.

NGUYEN, L. T. H. \& N. DE PAUW. 2002. The invasive Corbicula species (Bivalvia, Corbiculidae) and the sediment quality in Flanders, Belgium. Belgian Journal of Zoology, 132: 41-48.

PHELPS, H. 1994. The asiatic clam (Corbicula fluminea) invasion and system-level ecological change in the Potomac River Estuary near Washington, D.C. Estuaries, 17: 614-621.

R DEVELOPMENT CORE TEAM 2012. R: A language and environment for statistical computing. R Foundation for Statistical Computing, Vienna, Austria.

RODRIGUES, A. M., V. QUINTINO, L. SAMPAIO, R. FREITAS \& R. NEVES. 2011. Benthic biodiversity patterns in Ria de Aveiro, Western Portugal: Environmental-biological relationships. Estuarine Coastal and Shelf Science, 95: 338-348.

SAKAI, A. K., F. W. ALLENDORF, J. S. HOLT, D. M. LODGE, J. MOLOFSKY, K. A. WITH \& S. WELLER. 2001. The population biology of invasive species. Annual Review of Ecology and Systematics, 32: 305-332.

SOUSA, R. 2003. Estrutura das comunidades de macroinvertebrados bentónicos presentes no estuário do rio Lima [Structure of benthic macroinvertebrate communities present in the Lima river estuary]. Master's thesis. Universidade do Porto.

SOUSA, R., L. GUILHERMINO \& C. ANTUNES. 2005. Molluscan fauna in the freshwater tidal area of the River Minho estuary, NW of Iberian Peninsula. Annales de Limnologie-International Journal of Limnology, 41: 141-147.

SOUSA, R., C. ANTUNES, L. GUILHERMINO. 2006. Factors influencing the occurrence and distribution of Corbicula fluminea (Müller, 1774) in the River Lima estuary. Annales de LimnologieInternational Journal of Limnology, 42: 165-171. 
SOUSA, R., R. FREIRE, M. RUFINO, J. MÉNDEZ, M. GASPAR, C. ANTUNES \& L. GUILHERMINO. 2007a. Genetic and shell morphological variability of the invasive bivalve Corbicula fluminea (Müller, 1774) in two Portuguese estuaries. Estuarine Coastal and Shelf Science, 74: 166-174.

SOUSA, R., C. ANTUNES \& L. GUILHERMINO. 2007b. Species composition and monthly variation of the Molluscan fauna in the freshwater subtidal area of the River Minho estuary. Estuarine Coastal and Shelf Science, 75: 90-100.

SOUSA, R., A. J. NOGUEIRA, M. B. GASPAR, C. ANTUNES \& L. GUILHERMINO. 2008a. Growth and extremely high production of the non-indigenous invasive species Corbicula fluminea (Müller, 1774): Possible implications for ecosystem functioning. Estuarine Coastal and Shelf Science, 80: 289-295.

SOUSA, R., C. ANTUNES \& L. GUILHERMINO. 2008b. Ecology of the invasive Asian clam Corbicula fluminea (Müller, 1774) in aquatic ecosystems?: an overview. Annales de LimnologieInternational Journal of Limnology, 44: 85-94.
SOUSA, R., S. COSTA-DIAS, L. GUILHERMINO \& C. ANTUNES. 2008c. Minho River tidal freshwater wetlands: threats to faunal biodiversity. Aquatic Biology, 3: 237-250.

SOUSA, R., J. L. GUTIÉRREZ \& D. C. ALDRIDGE. 2009. Non-indigenous invasive bivalves as ecosystem engineers. Biological Invasions, 11: 2367-2385.

STACHOWICZ, J. J. S., H. F. RIED \& R. W. O. SMAN. 2002. Biodiversity, invasion resistance, and marine ecosystem function: Reconciling pattern and process. Ecology, 83: 2575-2590.

WIJNHOVEN, S., G. VAN DERVELDE \& H. HUMMEL. 2011. Is Corophium multisetosum (Stock, 1952) an Exotic Invasive Species in Europe? Distribution, Habitat, and Recent Observations in the Netherlands. Crustaceana, 84: 975-1011.

WINER, B. J., D. R. BROWN \& K. M. MICHELS. 1991. Statistical Principles in Experimental Design. New York, USA: McGraw-Hill.

WORM, B., E. B. BARBIER, N. BEAUMONT, J. E. DUFFY, C. FOLKE, B. S. HALPERN \& R. WATSON. 2006. Impacts of biodiversity loss on ocean ecosystem services. Science, 314: 787-90. 